\title{
Neuroscience, Early Childhood Education and Play: We are Doing it Right!
}

\author{
Stephen Rushton
}

Published online: 12 February 2011

(C) Springer Science+Business Media, LLC 2011

\begin{abstract}
This editorial examines neuroscience and its impact on the field of education. Starting with a narrative between two young children, the author intertwines research with basic principles of learning, using the interaction between two 4-year-olds to illustrate the precepts. The four principles are: (1) the brain is uniquely organized; (2) the brain is continually growing; (3) a "brain-compatible" classroom enables connection of learning to positive emotions; and (4) children's brains need to be immersed in real-life, hands-on, and meaningful learning experiences. The editorial concludes with an illustration of how the brain works while two children are playing at the small animal center in their classroom.
\end{abstract}

Keywords Neuroscience · Play · Early childhood education $\cdot$ Four principles

\section{The Power of Emotions}

Returning from our weekly Kindergarten swimming lessons, Alexandra was in a hurry to get to the classroom and have her snack before launching into her hour of free exploration. On her way, she passed a group of boys enjoying their snack. They were engrossed in a deep conversation about dinosaurs. Alexandra's backpack inadvertently knocked over Michael's glass-lined thermos container, a relic from the past. The inside shattered when it hit the ground. Alexandra turned pale, became speechless, and was afraid to move. You could see the excitement drain out of her. Michael, on the other hand, looked

S. Rushton $(\bowtie)$

University of South Florida, Sarasota, FL 34243, USA

e-mail: srushton@sar.usf.edu fascinated as he held up the thermos and a trickling sound rattled inside, somewhat akin to a modern-day rain-stick.

I watched Alexandra's face turn red, consumed with some internal sense of guilt. Nothing was said between the two. A moment etched in time. Should I intervene? What would I say? I stood motionless, waiting. Decisively, Alexandra ran to the paint center, grabbed a long, thin brush, dipped it in the black paint and started methodically painting. She began at the top right corner and slowly, deliberately, painted the paper one precise stroke at a time. Until the once-white paper was covered in black paint. Then she took a deep breath and let it all out as she gazed toward her emotions displayed on the paper. A smile slowly spread across her face. Placing the paint brush back in its container, she sprang back into life, headed over to the house center and started playing as though nothing had happened.

(Junior Kindergarten, Ontario, Canada).

\section{Introduction}

Many years have passed since I taught Kindergarten. And yet the memory of watching Alexander's shock at breaking Michael's thermos and the subsequent release of her emotions through the painting etched a vivid memory within my own neuro-pathways.

I often share this story with my pre-service students and early childhood teachers, for a variety of reasons. Primarily, it models part of the neuroscience of learning and how fear can be aroused once the amygdala has been activated. Alexandra saw the thermos fall and heard the glass interior shatter. The sound waves and visual stimulation made their way to her ears and eyes, and then deep into her brain to Alexandra's thalamus. The waves had been converted into 
an electro-chemical reaction, and at the thalamus, decisions were made as to where to send the impulse next (Sylwester 2010). They headed to the parts of the brain that process particular information; in this case, the occipital and temporal lobes. There, through an exchange of chemicals in the synaptic space between neurons, memories and information were formed. At the same time that the thalamus sent the incoming stimuli to the appropriate parts of the brain, it sent the same signal to Alexandra's amygdala, right next door.

This organ is critical as it sorts for danger in the environment without consulting with the rational processes of the frontal lobes (Rushton and Juola-Rushton in press; Whalen and Phelps 2009). In Alexandra's case, she saw the thermos fall and heard the glass break, froze for a few seconds, and turned a shade of red. A series of reactions had taken place, and a release of neurotransmitters and hormones had aroused her nervous system. Once her frontal lobe caught up, Alexandra knew instinctively what to do in order to release her anxieties. Through color and movement of the brush, Alexandra relieved herself of what could have been an overwhelming rupture of emotion.

A second reason I share this story with my teachers in training is that this brief interchange between Michael and Alexandra illustrates an important philosophy in early childhood education: It is essential that we allow young children to make their own decisions and choices. Alexandra needed to integrate her emotional, physical, and mental processes on her own terms. Giving her the freedom to choose her next step was critical. She had an internal sense of what she would need to do and decided that painting a canvas black would help. Incidentally, all of Alexandra's paintings prior to this were of bright rainbows, colorful homes, and her family.

I believe this narrative also helps to depict an important aspect, and perhaps even a growing concern, for early childhood educators. As teachers, we make hundreds of decisions daily. Knowing when to step in, take over, wait, model, and lead is a balancing act that requires much skill. How much freedom do we give? When do we intervene in the course of a child's learning? And now standardized testing has made its way down to 1 st-grade classrooms. As a result, Kindergarten classes become the training grounds for success in 1st grade, and not necessarily a place where children can explore, grow, and learn at their own pace. What is our role as educators in this new world of standardized education? This editorial will review and address some of these important questions from the perspective of brain-based education and a constructivist lens.

We live in uncertain times. Once again, the field of early childhood education balances between two contrasting educational and political perspectives. On the one hand, we have educators such as Otto Weininger, professor emeritus in the Early Childhood Education Department at OISE/UT, whose now-eloquent expression-“You can't make children grow faster by pushing them, just as you can't make flowers grow faster by pulling them"-depicts the essence of a constructivist's philosophical belief that young children need to unfold at their own developmental pace. Constructivism is practiced by those early childhood educators who subscribe to the tenets of developmentally appropriate practices (Bredekamp and Copple 1987; Copple and Bredekamp 2010), brain-based research (Rushton et al. 2009; Sylwester 2010), and multiple intelligences (Gardner 1993).

Juxtaposed to constructivism as a way of teaching our young are educators who believe in a more traditional, teacher-led approach to education. Many of these educators are guided by the political pressure for standardized testing. Accountability and setting measurable standards are fast becoming just as synonymous with early childhood as the concept of developmentally appropriate practices (Schiller and Willis 2008). An emotional dissonance is rising in early childhood educators as they balance the two. Funding is directly linked to testing, and in some states this begins as early as pre-Kindergarten (Golan et al. 2008). This new wave has been emerging in our educational arena for nearly a decade. It is driving the belief that all children need to be on the same page at the same time. Beginning with the 1983 report A Nation at Risk: The Imperative for Educational Reform (National Commission on Excellence in Education 1983) to various Commission Reports during the 1990s, to the most influential initiative, the No Child Left Behind Act of 2001, early childhood educators have been contending with political pressure and struggling to balance assessment with best practices (Rushton and JuolaRushton 2008).

Indeed, today's children certainly face a world that is unique, fast-paced, and accelerating at a level that never existed before. Information on the Internet is in competition with, and in many cases outperforming, classroom instruction, not only in terms of the availability of information but the exponential rate at which it changes. Young children's exposure to playing games and picking up misinformation via the Internet is a novel concept in the world of teaching, one that needs addressing. When compared to a teacher, the artificial world created by interactive, high-definition video games such as Xboxes, Wiis, and PS3s can be far more enticing. Wolfe (2007) states that every 2 years, approximately half of what we know could be obsolete, which begs the questions, what are we teaching, and why?

Clearly, times changed when the industrial age shifted to the information era. Our way of thinking and the neuropathways of our young are also changing (Diamond and Hopson 1999). It has become clear that educators need not 
only to help children to do well in school but also-and more importantly - to help children survive in a world we ourselves cannot truly comprehend, see, or even imagine (Wolfe 2007). It is our task as early childhood educators to help today's children learn to analyze, synthesize, and clarify information, not simply recite facts and figures from the past. Never before in the history of early childhood education in the U.S. has this truth been so realized as we move into a new political era. We are in a time of embracing and understanding the heart of the whole child.

\section{Research to Support Early Childhood Educators' Approach to Teaching}

Research during the past decade provides a clear road map of how best to accomplish the difficult task of balancing assessment (Jones et al. 2007) to standardized outcomes (Drew et al. 2008) with best practices (Copple and Bredekamp 2010). With the exciting convergence of studies from the fields of neuroscience (Diamond and Hopson 1999; Friederici 2006; Nelson et al. 2006; Sylwester 2010) and cognitive psychology (Gardner 1993), educators (Bergen and Coscia 2001; Gallagher 2005; Rushton et al. 2009; and Rushton and Juola-Rushton in press) are now making important links to help early childhood educators stay true to their training and knowledge about hands-on, developmentally appropriate experiences that allow young children to learn best.

In their paper titled Shaping the learning environment: Connecting developmentally appropriate practices to brain research, Rushton and Larkin (2001) connected nine of the 12 DAP position statements as outlined in Bredekamp and Copple's (1987) initial paper to nine brain-based principles gathered from the literature in the field. Our intent was to help teachers connect the importance of developing strong curricular components that immerse children's experiences in real-life situations, allowing the child's natural curiosity to develop. At that time, we had hoped to draw parallels between how the cognitive processes of the brain work and the ties to early childhood. Fortunately, many teachers of young children are working toward developing the brain's natural way of learning when they listen and interact with the child. The opening narrative illustrates how the child's emotional, intellectual and physical domains naturally integrate by providing room for their own self-discovery. Many teachers are becoming knowledgeable about the neurosciences, are well versed in DAP, and create engaging, meaningful experiences for their children to explore, assess, and learn. It is through these exciting yet complicated times that early childhood educators can deepen their educational pedagogy without childhood needs being sacrificed.
Similarly, positive, stimulating environments where young children are free to select their own learning help to reduce stress in the classroom and allow for great flexibility and creativity. Millions of neuro-pathways are readily forming and connecting within the child's brain. These connections will support children throughout their entire lives. In addition, the use of play as a form of learning, when left open-ended, is congruent with individual differences. Each brain's structure is designed to process information uniquely, much like Michael and Alexandria taught us in the opening vignette. Playful learning allows for individual differences and mastery to occur.

Finally, the child's 'mirror neurons' reflect their external world. Research (Iacoboni et al. 2005) suggests that a positive, enthusiastic teacher sends signals to the child's mirror neurons, which, in turn, can impact how they receive the learning objectives being delivered. How we present not only ourselves, but also the phenomenal journey of learning, is critical to the child's emotional development. It would be amazing if we could support children in such an open, engaging environment that they don't want to leave when the school day ends.

In 2007, Pat Wolfe, an educational consultant and expert on brain research, suggested that the bridge between the field of neuroscience research and education is not the job of neuroscientists, but instead, that of educators. It is easy to become overwhelmed with the language that is often associated with neuroscience. Such neurological terms as occipital and parietal lobes, amygdala, thalamus, neurons, dendrites, neurotransmitters, etc., may be difficult to put into the context of a Kindergarten classroom. The idea that a connection exists between the firing of an electro-biochemical synaptic reaction taking place between neurons in a 4-year-old's brain, which may release neurotransmitters such as dopamine or serotonin, and the child's ability to stay focused and learn is a stretch for most of us. Comfortable with the terminology or not, it is our responsibility as early childhood educators to understand that every child each school year represents a virtual explosion of dendritic growth. We are so fortunate to be in a profession where we can create learning opportunities to best support young children's development and their biological wiring, so let's start there.

\section{Brain Principles}

Leslie Hart (1983, p. 21) states, "Anyone who does not have a thorough, holistic grasp of the brain's architecture, purposes, and main ways of operating is as far behind the times as an automobile designer without a full understanding of engines." With this in mind, here are the four basic principles of brain-based learning and applications, to 
help you get to know 'the engines' you mold each day. It is our belief that many ECEs are already skilled and armed with the knowledge of what best practices are. It is also our belief that any developmentally appropriate program focuses on the 'whole child'; that is, it comes from a stance of how can we best touch the mental, emotional, social, and physical life of the young child. As such, it is already involved in practices that are brain-compatible and reflects the four principles that follow.

\section{Principle Number One}

Every brain is uniquely organized. It's easy to focus on the children in your class who are the most persistent. We all know the old adage, 'the squeaky wheel gets the grease.' Remember, each child's brain thinks, feels and learns differently. By providing skills-leveled materials, those students who are below, average, and above can not only celebrate successes, but also maximize their development to venture on to more complex tasks. For example, when reviewing the objective of a child's becoming secure in their alphabet awareness, we would require a variety of materials to support this goal. We would stock the writing area with various materials, based on the students' developmental needs, such as sandpaper letters for finger tracing, sand trays for letter scrolling, paints, brushes, and jumbo pencils for scribing.

\section{Principle Number Two}

The brain is continually growing, changing and adapting to the environment. Intelligence is not fixed at birth but fluctuates throughout life, depending upon the stimulation of the environment, hormonal levels and other chemical reactions taking place throughout the body. The fact that children today spend more time in school than with their primary caregivers requires educators to be far more diligent about the environments they are creating. During the first 5 years of a child's life, billions of neurons are being connected, depending upon the stimulus of the environment (Miller and Cummings 2007). Each day we greet our students with a warm welcome, encourage them as individuals, provide personal challenges, involve them in the development of the classroom environment, and support individual differences. Educators are aware of the changes that take place in children from day to day, month to month. Many of these changes are biologically driven and unique from child to child. Our job is to notice, accept, and modify the curriculum to each student.

\section{Principle Number Three}

A 'brain-compatible' classroom enables connection of learning to positive emotions. The most naturalistic way for this to occur is by allowing students to make relevant decisions and choices about their learning. I am not suggesting we give full rein and see what happens. Instead, our curriculum objectives are set as a target and our preparation to meet these targets requires thought and understanding of each child's strength and weaknesses. Ultimately, it is the students who guide the learning and we, the facilitators, course-correct along the way. Given that each child's brain is unique and varying levels of individuality exist, it takes a special educator to not want to force each child into a lockstep curriculum. Different levels of neurochemicals create different emotions. Too much of one chemical, or too little, (say, either dopamine or serotonin) will impact the child's mood and therefore their ability to want to learn or simply respond.

\section{The Fourth Brain Principle}

Children's brains need to be immersed in real life, handson, and meaningful learning experiences that are intertwined with a commonality and require some form of problem-solving. Visiting early childhood classrooms and seeing the children interacting with their world is an exciting endeavor. When we approach the classroom environments, the teachers who continue with a small group as if no one is there, lost in the exploration of shapes with straight or curved edges, speak volumes. Equally communicative are, the children who question or invite us into their learning adventures, talking us through it the whole way. These are the developments of critical thinking that reach the core of dendritic growth.

Either you recognize yourself within some of these simple principles provided above, or you now have a definitive direction for your teaching. We realize that there is a lot to the brain lingo (dendrites, synapses, neurons, etc.). We encourage you to stretch yourself a bit and actually see if you can get inside the heads of your students.

\section{Brief Overview of the Brain's Mechanism}

In short, each experience a young child has typically involves one or more of their senses. As the child interacts with the environment, various stimuli enter the body via the five senses. These experiences are then converted into electrical/chemical impulses that travel, via nerves impulses, to the thalamus - an almond-shaped organ in the center of the brain. This important organ assigns the incoming stimuli to one of the four lobes (occipital, temporal, parietal and pre-frontal) or the motor cortex part of the brain for further processing.

For instance, imagine two children who are playing with different toy animals and are classifying them into types 
(wild, farm, pets). Both children are using numerous portions of their brains at once, all very similar, yet different neuro-pathways are used in different sequence to get to the same result. To begin with, picture the two students subdividing the animals into 'farm animals,' 'predatory animals' and 'house pets'. Light rays enter the eyes' pupils, convert to an electro-chemical impulse behind the retina, and follow neurons to the thalamus, which sends the signal to the occipital lobe's millions of cells, each one designed for a specific task. Some cells help determine the different shapes of the animals, others the various colors, and some help sort the varying shades of a particular color. As the children pick up the different animals and classify them according to texture (say, the difference between wood and plastic), their fingers connect with the material. The nerves from their finger-tips send a similar electro-chemical message to the nerves within the hand. This travels up the arm to the spinal column and again to the thalamus. The signal is then sent directly to the motor cortex located midline center of the brain, which allows the child to place the animal in one pile or another. As the child decides in which pile to place the animal, the pre-frontal lobe is also activated, as this is the decision-making center of the brain. The pre-fontal lobe is also considered the executive center of the brain, and as children grow into adults, this portion of the brain develops further, allowing sound judgments to be made.

Although this is a highly simplified explanation of how the brain works, it is clear that the process is both natural and complicated. Let's review the function of some of the terms used above.

Table 1 Overview of brain terminology

Electrical/chemical Used by neurons to signal to each other and to impulse non-neuronal cells

Thalamus

The information messenger between the cortex, brain stem, and other cortical structures. Contributions include perception, timing and movement

Occipital lobe The primary visual area of the brain. Two important pathways of information that originate in the occipital lobes are the dorsal and ventral streams. The dorsal stream is what projects to the parietal lobes and then processes the location of the object. One of the functions of the ventral stream is to then process what that object was

Temporal lobe Functions include perception, face recognition, memory acquisition, understanding language, and emotional reactions

Parietal lobe Integrates information from the ventral visual pathways and dorsal visual pathways, thus allowing us to coordinate our movement in response to the object in the environment
Table 1 continued

\begin{tabular}{ll}
\hline Pre-frontal lobe & $\begin{array}{c}\text { Processes "higher" brain functions. A part of the } \\
\text { executive system that refers to our ability to } \\
\text { plan, reason, and make judgments. Also } \\
\text { important contributor to the assessment and } \\
\text { control of appropriate social behaviors due to } \\
\text { involvement in personality and emotion }\end{array}$ \\
Gotor cortex & $\begin{array}{l}\text { Generates the neural impulses controlling the } \\
\text { execution of movement }\end{array}$ \\
Retina & $\begin{array}{l}\text { Light-sensitive tissue lining the inner surface of } \\
\text { the eye }\end{array}$ \\
Nerves & $\begin{array}{l}\text { Provide the pathway for the electro-chemical } \\
\text { impulses that are transmitted along axons }\end{array}$ \\
Spinal column & $\begin{array}{c}\text { Also known as the vertebral column, backbone } \\
\text { or spine. It houses and protects the spinal cord } \\
\text { in its spinal canal }\end{array}$ \\
\hline
\end{tabular}

To find more information about the parts of the brain, you can go to wikipedia.com, or check out the interactive applications via Apple's iTunes.

\section{Conclusion}

Thirty years ago few educators would have predicted that many schools in 4th and 5th grade would send their children home with Apple laptops to complete homework, or that most schools would have computer laptop trolleys that are shared between two classes. Children are exposed to stimulations, sounds, sights that often blur reality. Modern games are often more intense than real life and certainly have a way of stimulating the opiate receptors of the brain "Michael, Michael are you there?" Mom yells upstairs, knowing her child has been classified as ADHD at school yet can't seem to pull himself away from the video game hour after hour at home. Today's early childhood educators need to be genuine, engaging, intentional, and aware of what is affecting their students.

Young children's brains are expanding at an incredible rate. Miller and Cummings (2007) estimate that by the time a child reaches the age of 5, more than 100 billion neurons have made connections within the cerebral cortex (the grey matter of the brain). In truth, many of these neurons, if not used, die out, as neurons are initially overproduced so the child can be supported to navigate through life. Learning one of the 3,000 languages that are present (Nevills and Wolfe 2009) and making decisions about when to crawl, stand, walk, and talk are both developmental and connected to the neurons in the brain, making strong healthy connections. The stronger the connections between neurons, the strong and faster the reaction will be in recalling information (Gallagher 2005). It's exciting to be part of the 
intense growth in a young child's brain. Early childhood educators literally have the ability to help shape a child's mind.

\section{References}

Bergen, D., \& Coscia, J. (2001). Brain research and childhood education: Implications for educators. Olney, MD: Association for Childhood Education International.

Bredekamp S., \& Copple, C. (Eds.). (1987). Developmentally appropriate practice in early childhood programs serving children from birth through age 8 (Exp. ed.). Washington, DC: NAEYC.

Copple, C., and Bredekamp, S. (Eds.). (2010). Developmentally appropriate practice in early childhood programs serving children from birth through age 8, (Exp. 3rd ed.). Washington, DC: NAEYC.

Diamond, M., \& Hopson, J. (1999). Magic trees of the mind: How to nurture your child's intelligence, creativity, and healthy emotions from birth through adolescence. New York, NY: Penguin Putnam.

Drew, W., Christie, J., Johnson, J., Meckley, A., \& Nell, M. (2008). Constructive play: A value-added strategy for meeting early learning standards. Young Children, 63(4), 38-44.

Friederici, A. D. (2006). The neural basis of language development and its impairment. Neuron, 52I, 108-120.

Gallagher, K. (2005). Brain research and early childhood development: A primer for developmentally appropriate practice. Young Children, 60(4), 12-20.

Gardner, H. (1993). Multiple intelligences: The theory in practice. New York, NY: Basic Books.

Golan, S., Petersen, D., \& Spiker, D. (2008). Kindergarten assessment process planning report: SRI project 18631. Menlo Park, CA: SRI International.

Hart, L. (1983). Human brain and human learning. New York, NY: Longman.
Iacoboni, M., Molnar-Szakacs, I., Gallese, V., Buccino, G., Mazziotta, J. C., \& Rizzolatti, G. (2005). Grasping the intentions of others with one's own mirror neuron system. PLoS Biology, 3(3), e79.

Jones, P., Ataya, R., \& Carr, J. (Eds.). (2007). A pig don't get fatter the more you weigh it: Balancing assessment for the classroom. New York, NY: Teachers College.

Miller, B., \& Cummings, J. (Eds.). (2007). The human frontal lobes. New York, NY: Guilford.

National Commission on Excellence in Education. (1983). A nation at risk: The imperative of educational reform. East Lansing, MI: National Center for Research on Teacher Learning. (ERIC Document Reproduction Service No. SP 027 831).

Nelson, C. A., de Haan, M., \& Thomas, K. M. (2006). Neural bases of cognitive development. In W. Damon, R. Lerner, D. Kuhn, \& R. Siegler (Eds.), Handbook of child psychology (Vol. 2). Hoboken, NJ: John Wiley.

Nevills, A., \& Wolfe, P. (2009). Building the reading brain preK-3. Thousand Oaks, CA: Corwin.

Rushton, S., \& Juola-Rushton, A. (2008). Classroom learning environment, brain research and the no child left behind initiative: 6 years later. Early Childhood Education Journal, 36(1), 89-92.

Rushton, S., Juola-Rushton, A., \& Larkin, E. (2009). Neuroscience, play and early childhood education: Connections, implications and assessment. Early Childhood Education Journal, 37(5), 351-361.

Rushton, S., \& Larkin, E. (2001). Shaping the learning environment: Connecting developmentally appropriate practices to brain research. Early Childhood Education Journal, 29(1), 25-33.

Schiller, P., \& Willis, C. (2008). Using brain-based teaching strategies to create supportive early childhood environments that address learning standards. Young Children, 63(4), 52-55.

Sylwester, R. (2010). A child's brain: The need for nurture. Thousand Oaks, CA: Corwin.

Whalen, P., \& Phelps, E. (Eds.). (2009). The human amygdala. New York, NY: Guilford.

Wolfe, P. (2007). Mind, memory and learning; Translating brain research to classroom practices. Napa Valley: CA. 